\title{
Native Gold of the Porphyry Copper Mineralization in the Borov Dol Deposit (Republic of Macedonia)
}

\author{
A. V. Volkov, V. Stefanova, T. Serafimovski, \\ and Corresponding Member of the RAS A. A. Sidorov \\ Received April 29, 2008
}

DOI: $10.1134 / \mathrm{S} 1028334 \mathrm{X} 08070015$

Mineralogical study of gold in disseminated porphyry copper ores is complicated by its fine (often micrometer size) segregations and low contents $(0 . n \mathrm{~g} / \mathrm{t})$. This paper presents the results of investigation of gold in porphyry copper ores of the Borov Dol deposit (Republic of Macedonia) by an ingenious method.

Macedonia is located in the Serbian-Macedonian sector of the Eurasian metallogenic belt of the Tethys. The metallogeny of this region is related to the Ceno- zoic activation and formation of the volcanoplutonic rock complex in the course of scattered spreading [1].

The major porphyry copper deposits of Macedonia belong to the Leche-Chaldikidi metallogenic zone [2], which is sandwiched between the Serbian-Macedonian massif and the Vardar zone. Porphyry deposits of the Leche-Chaldikidi zone are genetically related to Tertiary minor subvolcanic stocks of the calc-alkaline composition, e.g., Bučim, Tular, Borov Dol, and Ilovica in Macedonia; Vakhi, Gerkaria, and Potokerasia in Greece; and others (Table 1) [3]. Reserves in these

Table 1. Characteristics of porphyry copper deposits and occurrences in Macedonia and Greece

\begin{tabular}{|c|c|c|c|c|}
\hline Deposit & Kiseljak & Buxim & Borov Dol & Vakhi \\
\hline Enclosing rocks & Andesites & Gneisses and andesites & Andesites & Rhyodacites \\
\hline Age, $\mathrm{Ma}$ & $12-23$ & $25-28$ & $24-28$ & 30 \\
\hline Horizontal projection & $0.24 \mathrm{~km}^{2}$ & $0.25 \mathrm{~km}^{2}$ & $0.15 \mathrm{~km}^{2}$ & $150 \times 700 \mathrm{~m}$ \\
\hline Vertical dimension, $\mathrm{m}$ & $300-500$ & 250 & 300 & 500 \\
\hline Content & $\begin{array}{l}0.3 \% \mathrm{Cu}, 0.3 \mathrm{~g} / \mathrm{t} \mathrm{Au} \\
1.0 \mathrm{~g} / \mathrm{t} \mathrm{Ag}, 23 \mathrm{~g} / \mathrm{t} \mathrm{Mo} \\
4-10 \%-\text { pyrite }\end{array}$ & $\begin{array}{l}0.3 \% \mathrm{Cu}, 0.5 \mathrm{~g} / \mathrm{t} \mathrm{Au} \\
1.1 \mathrm{~g} / \mathrm{t} \mathrm{Ag}, 13 \mathrm{~g} / \mathrm{t} \mathrm{Mo} \\
1-4 \%-\mathrm{pyrite}, \\
\text { traces of: } \mathrm{Pd}, \mathrm{Se}, \mathrm{Te}\end{array}$ & $\begin{array}{l}0.3 \% \mathrm{Cu}, 0.25 \mathrm{~g} / \mathrm{t} \mathrm{Au} \\
150 \mathrm{~g} / \mathrm{t} \mathrm{Ag}, 24 \mathrm{~g} / \mathrm{t} \mathrm{Mo} \\
2 \% \text { - pyrite }\end{array}$ & $\begin{array}{l}0.3 \% \mathrm{Cu}, 0.15 \mathrm{~g} / \mathrm{t} \mathrm{Au} \\
0.35 \mathrm{~g} / \mathrm{t} \mathrm{Ag}, 20 \mathrm{~g} / \mathrm{t} \mathrm{Mo}\end{array}$ \\
\hline Deposit & Pondokerasia & Skories & Kadiitsa & Ilovica \\
\hline Enclosing rocks & $\begin{array}{l}\text { Rhyodacites and } \\
\text { granosyenites }\end{array}$ & Granodiorite porphyres & $\begin{array}{l}\text { Quartz latites and } \\
\text { schists }\end{array}$ & $\begin{array}{l}\text { Quartz latites and } \\
\text { biotite granites }\end{array}$ \\
\hline Age, Ma & 32 & 29.6 & 27.5 & $?$ \\
\hline Horizontal projection & $300 \times 400 \mathrm{~m}$ & $100 \times 200 \mathrm{~m}$ & $300 \times 400 \mathrm{~m}$ & $1.0 \mathrm{~km}^{2}$ \\
\hline Vertical dimension, $\mathrm{m}$ & 500 & 700 & 300 & 300 \\
\hline Content & $\begin{array}{l}0.3 \% \mathrm{Cu}, 0.3 \mathrm{~g} / \mathrm{t} \mathrm{Au} \\
0.35 \mathrm{~g} / \mathrm{t} \mathrm{Ag}, 20 \mathrm{~g} / \mathrm{t} \mathrm{Mo}\end{array}$ & $\begin{array}{l}0.5 \% \mathrm{Cu}, 0.7 \mathrm{~g} / \mathrm{t} \mathrm{Au}, \\
2.5 \mathrm{~g} / \mathrm{t} \mathrm{Ag}, \\
\text { traces of: } \mathrm{Pd}, \mathrm{Te}, \mathrm{Pt}\end{array}$ & $\begin{array}{l}0.2 \% \mathrm{Cu}, 0.2 \mathrm{~g} / \mathrm{t} \mathrm{Au} \\
0.35 \mathrm{~g} / \mathrm{t} \mathrm{Ag}, 20 \mathrm{~g} / \mathrm{t} \mathrm{Mo}\end{array}$ & $\begin{array}{l}0.5 \% \mathrm{Cu}, 0.3-1.0 \mathrm{~g} / \mathrm{t} \\
\mathrm{Au}, 5 \mathrm{~g} / \mathrm{t} \mathrm{Ag}, 50 \mathrm{~g} / \mathrm{t} \mathrm{Mo}\end{array}$ \\
\hline
\end{tabular}

Institute of Geology of Ore Deposits, Petrography, Mineralogy, and Geochemistry, Russian Academy of Sciences, Staromonetnyi per. 35, Moscow, 119017 Russia

e-mail:tma2I05@ya.ru

Faculty of Mining and Geology, Kiril and Metodie University of Skopje, Goce Delcev 89, 92000 Shtip, Republic of Macedonia 


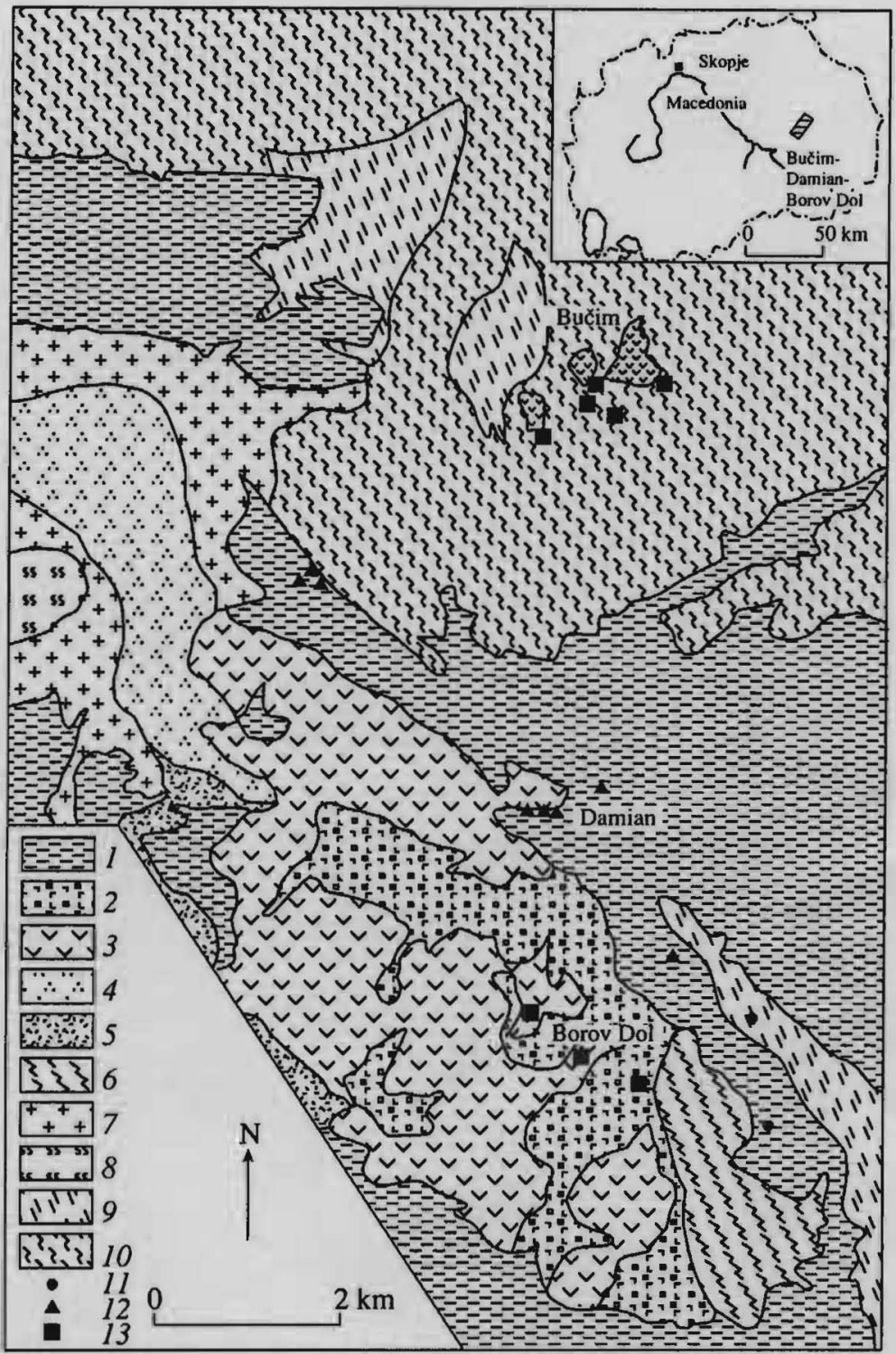

Fig. 1. Geological map of the Bučim-Damian-Borov Dol ore region [6]. (I) Paleogene, Neogene, and Quaternary sedimentary rocks; (2) Pyroclasts; (3) andesites and latites; (4) Quaternary flysch; (5) carbonatites; (6) carbonate schists; (7) granites; (8) serpentinites; (9) muscovite schists; (10) gneisses; (II) Pb-Zn vein mineralization; (12) Fe skarn mineralization; (I3) porphyry copper mineralization.

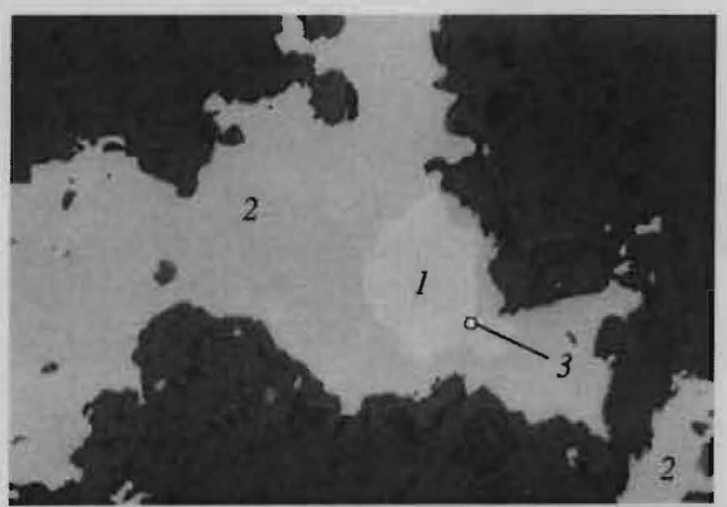

Fig. 2. (2) A large allotriomorphic chalcopyrite grain with $(I)$ polydymite inclusion and (3) fine-dispersed gold. Polished section. Magn. 126x. 

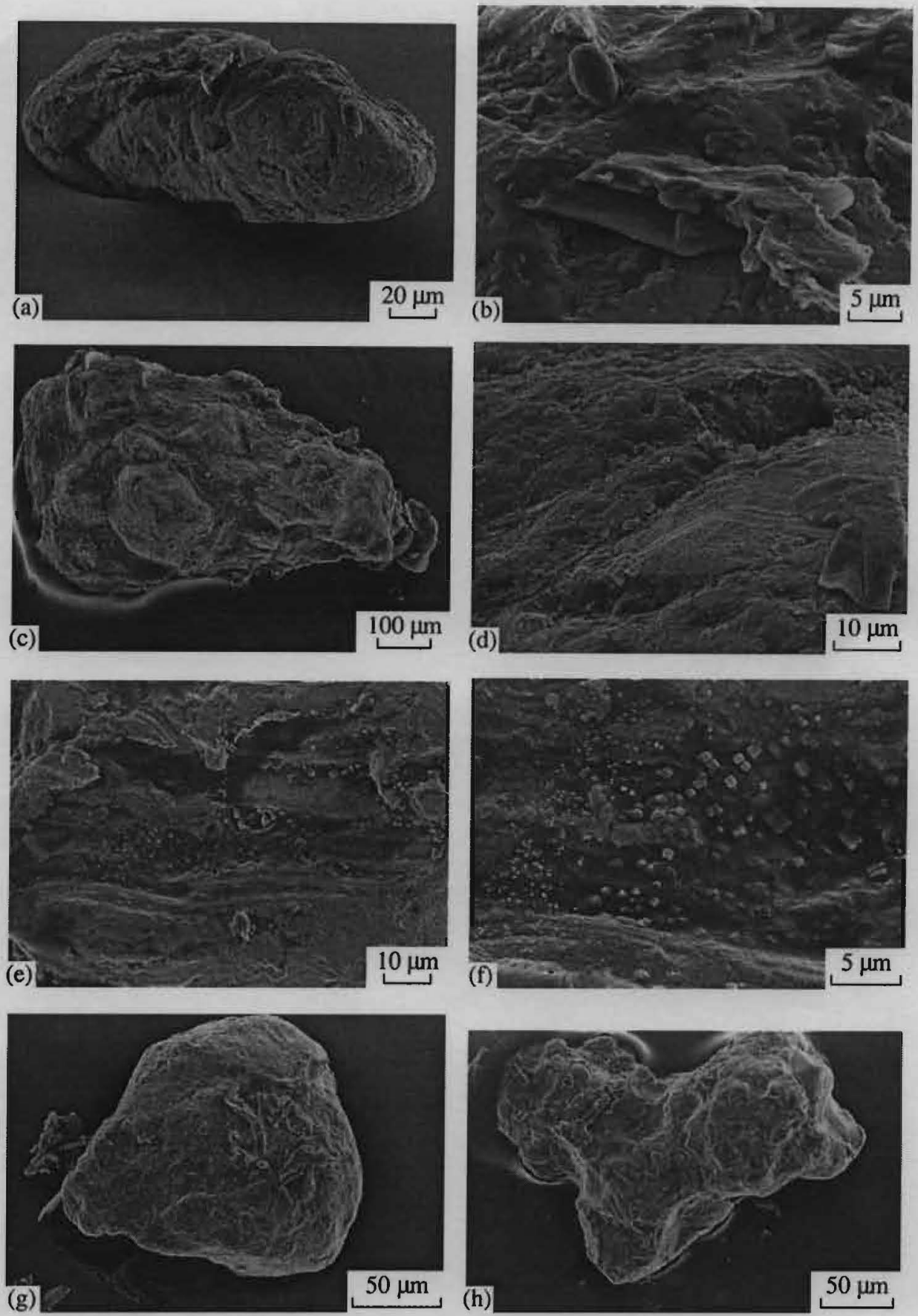

Fig. 3. Morphology of gold segregations and aggregates from the Borov Dol deposit: (a) elongate-columnar gold aggregate, (b) gold flakes (closeup of Fig. 3a), (c) isometric gold aggregate, (d) closeup of Fig. 3c, (e, f) crystalline gold (closeup of Fig. 3d), (g) globular gold aggregate, (h) irregular isometric aggregate.

deposits do not exceed $1 \mathrm{Mt} \mathrm{Cu}$ (Table 1), but they are characterized by favorable mining-geological and economic conditions for exploitation. However, only the Bučim deposit (Macedonia) is mined at present. The Borov Dol deposit, a reserve body for the Bucim Mine, is located in the southern area of the Bucim-Damian-
Borov Dol ore region (approximately $150 \mathrm{~km}^{2}$ in area) located $5 \mathrm{~km}$ south of the Bucim deposit (Fig. 1). The Borov Dol deposit is characterized by the development of NW-striking faults that govern the Neogene quartzlatite dikes, necks, and lavas. Porphyry copper mineralization is paragenetically associated with the volcano- 
Table 2. Microprobe analyses of gold from the Borov Dol deposit

\begin{tabular}{|c|c|c|c|c|c|c|c|}
\hline \multirow{2}{*}{$\begin{array}{c}\text { Sample } \\
\text { no. }\end{array}$} & \multirow{2}{*}{$\begin{array}{l}\text { Sampling } \\
\text { point }\end{array}$} & \multicolumn{5}{|c|}{ Element } & \multirow{2}{*}{ Chemical formula } \\
\hline & & $\overline{\mathrm{Au}}$ & $\mathrm{Ag}$ & $\mathrm{Cu}$ & $\mathrm{Fe}$ & Total & \\
\hline \multirow[t]{4}{*}{ BD-5 } & Center & 95.50 & 4.26 & 0.53 & 0.08 & 100.4 & $\mathrm{Au}_{0.90} \mathrm{Ag}_{0.08} \mathrm{Cu}_{0.02}$ \\
\hline & Periphery & 94.31 & 4.4 & 0.42 & 0.08 & 99.21 & $\mathrm{Au}_{0.91} \mathrm{Ag}_{0.08} \mathrm{Cu}_{0.02}$ \\
\hline & The same & 95.40 & 3.56 & 0.46 & - & 99.42 & $\mathrm{Au}_{0.92} \mathrm{Ag}_{0.06} \mathrm{Cu}_{0.02}$ \\
\hline & Average & 95.07 & 4.07 & 0.47 & 0.05 & & \\
\hline \multirow[t]{4}{*}{ BD-5 } & Periphery & 90.96 & 8.92 & 0.55 & - & 100.4 & $\mathrm{Au}_{0.84} \mathrm{Ag}_{0.14} \mathrm{Cu}_{0.02}$ \\
\hline & The same & 87.31 & 12.66 & 0.39 & - & 100.3 & $\mathrm{Au}_{0.7} \mathrm{Ag}_{0.21} \mathrm{Cu}_{0.02}$ \\
\hline & The same & 83.45 & 15.77 & 0.34 & 0.26 & 99.82 & $\mathrm{Au}_{0.72} \mathrm{Ag}_{0.26} \mathrm{Cu}_{0.02}$ \\
\hline & Average & 87.24 & 12.45 & 0.42 & 0.08 & & \\
\hline \multirow[t]{3}{*}{ BD-9 } & Center & 90.87 & 8.51 & 0.61 & - & 99.98 & $\mathrm{Au}_{0.84} \mathrm{Ag}_{0.14} \mathrm{Cu}_{0.02}$ \\
\hline & Periphery & 86.02 & 12.60 & 0.60 & - & 99.22 & $\mathrm{Au}_{0.77} \mathrm{Ag}_{0.21} \mathrm{Cu}_{0.02}$ \\
\hline & Average & 88.44 & 10.55 & 0.65 & 0 & & \\
\hline \multirow{10}{*}{$\begin{array}{l}\text { BD-10, } \\
\text { grain } 1\end{array}$} & Center & 94.85 & 4.57 & 0.36 & 0.13 & 99.91 & $\mathrm{Au}_{0.91} \mathrm{Ag}_{0.08} \mathrm{Cu}_{0.01}$ \\
\hline & Periphery & 93.09 & 5.95 & 0.38 & - & 99.40 & $\mathrm{Au}_{0.90} \mathrm{Ag}_{0.09} \mathrm{Cu}_{0.01}$ \\
\hline & The same & 91.27 & 7.98 & 0.61 & 0.15 & 99.35 & $\mathrm{Au}_{0.85} \mathrm{Ag}_{0.13} \mathrm{Cu}_{0.02}$ \\
\hline & The same & 95.10 & 3.77 & 0.24 & - & 99.10 & $\mathrm{Au}_{0.92} \mathrm{Ag}_{0.07} \mathrm{Cu}_{0.01}$ \\
\hline & The same & 95.69 & 3.57 & 0.39 & - & 99.65 & $\mathrm{Au}_{0.93} \mathrm{Ag}_{0.06} \mathrm{Cu}_{0.01}$ \\
\hline & The same & 93.70 & 5.71 & 0.35 & - & 99.75 & $\mathrm{Au}_{0.90} \mathrm{Ag}_{0.09} \mathrm{Cu}_{0.01}$ \\
\hline & The same & 96.04 & 2.94 & 0.59 & - & 99.57 & $\mathrm{Au}_{0.93} \mathrm{Ag}_{0.05} \mathrm{Cu}_{0.02}$ \\
\hline & The same & 93.24 & 5.67 & 0.47 & 0.15 & 99.52 & $\mathrm{Au}_{0.90} \mathrm{Ag}_{0.09} \mathrm{Cu}_{0.01}$ \\
\hline & The same & 92.30 & 6.81 & 0.54 & - & 99.65 & $\mathrm{Au}_{0.87} \mathrm{Ag}_{0.11} \mathrm{Cu}_{0.02}$ \\
\hline & Average & 93.92 & 5.21 & 0.43 & 0.04 & & \\
\hline \multirow{9}{*}{$\begin{array}{l}\text { BD-10, } \\
\text { grain } 2\end{array}$} & Center & 93.54 & 5.62 & 0.39 & 0.09 & 99.63 & $\mathrm{Au}_{0.89} \mathrm{Ag}_{0.09} \mathrm{Cu}_{0.02}$ \\
\hline & Periphery & 89.31 & 9.82 & 0.59 & - & 99.72 & $\mathrm{Au}_{0.82} \mathrm{Ag}_{0.16} \mathrm{Cu}_{0.02}$ \\
\hline & The same & 88.39 & 10.05 & 1.56 & - & 99.58 & $\mathrm{Au}_{0.79} \mathrm{Ag}_{0.16} \mathrm{Cu}_{0.05}$ \\
\hline & The same & 87.71 & 11.65 & 0.31 & 0.09 & 99.75 & $\mathrm{Au}_{0.79} \mathrm{Ag}_{0.2} \mathrm{Cu}_{0.01}$ \\
\hline & The same & 90.71 & 8.81 & 0.47 & - & 99.98 & $\mathrm{Au}_{0.85} \mathrm{Ag}_{0.14} \mathrm{Cu}_{0.01}$ \\
\hline & The same & 93.13 & 6.05 & 0.50 & - & 99.67 & $\mathrm{Au}_{0.87} \mathrm{Ag}_{0.12} \mathrm{Cu}_{0.01}$ \\
\hline & The same & 90.65 & 8.97 & 0.29 & 0.08 & 99.98 & $\mathrm{Au}_{0.85} \mathrm{Ag}_{0.14} \mathrm{Cu}_{0.01}$ \\
\hline & The same & 92.26 & 6.54 & 0.53 & - & 99.32 & $\mathrm{Au}_{0.87} \mathrm{Ag}_{0.11} \mathrm{Cu}_{0.02}$ \\
\hline & Average & 90.71 & 8.43 & 0.58 & 0.03 & & \\
\hline \multirow{5}{*}{$\begin{array}{l}\text { BD-10, } \\
\text { grain } 3\end{array}$} & Center & 93.37 & 5.94 & 0.34 & 0.18 & 99.82 & $\mathrm{Au}_{0.88} \mathrm{Ag}_{0.11} \mathrm{Cu}_{0.01}$ \\
\hline & Periphery & 89.39 & 9.61 & 0.61 & 0.21 & 99.81 & $\mathrm{Au}_{0.81} \mathrm{Ag}_{0.16} \mathrm{Cu}_{0.02} \mathrm{Fe}_{0.01}$ \\
\hline & The same & 92.27 & 7.04 & 0.65 & 0.14 & 100.1 & $\mathrm{Au}_{0.85} \mathrm{Ag}_{0.13} \mathrm{Cu}_{0.02}$ \\
\hline & The same & 92.40 & 6.98 & 0.42 & 0.15 & 99.95 & $\mathrm{Au}_{0.86} \mathrm{Ag}_{0.12} \mathrm{Cu}_{0.02}$ \\
\hline & Average & 91.85 & 7.39 & 0.50 & 0.17 & & \\
\hline
\end{tabular}

plutonic complex (Fig. 1). The deposit has been known since 1930 when the first boreholes drilled in this region recovered copper mineralization $(\mathrm{Cu} 0.2-0.7 \%)$. Systematic exploration was performed in the years 1973-1977 after detailed regional geochemical, geophysical, and geological works. Boreholes were drilled in a $200 \times 200 \mathrm{~m}$ grid (up to $100 \times 100 \mathrm{~m}$ in the central part). The reserves were estimated at more than $40 \mathrm{Mt}$ with a grade of $0.3 \% \mathrm{Cu}$ and $0.28 \mathrm{~g} / \mathrm{t} \mathrm{Au}$ [4].
The ring-shaped porphyry copper mineralization surrounds an andesite pluton among older volcanic rocks that underwent intense hydrothermal alteration. Thus, precisely the older volcanic rocks serve as an oreenclosing medium for copper mineralization. Potassic metasomatism, biotitization, sericitization, and silicification are the typical hydrothermal alterations.

The morphology of the orebody along the dip is similar to that of the andesite stock. The mineralization 
is represented by dissemination $(70 \%)$ and stockwork (30\%) types. Primary ores are mainly composed of chalcopyrite. The subordinate minerals are represented by pyrite, molybdenite, magnetite, zolotite, and bornite. Enargite, fanitite, galena, and tennantite are rare.

Gold occurs in the Borov Dol deposit as two varieties (native mineral and telluride constituent) [2]. The native gold is associated with pyrites of all generations. This variety is observed as microinclusions in chalcopyrite 1 and polydymite (Fig. 2). In addition, the native gold occurs in sphalerite and the rock matrix. Based on microprobe data, the fineness of gold inclusions (up to $10 \mu \mathrm{m}$ across) is as high as $837 \%$.

We investigated gold under field and laboratory conditions. Samples of exogenic mineralization were panned according to the standard technology along rivers draining the Borov Dol deposit. Pyrite, magnetite, chalcopyrite, ilmenite, amphiboles, pyroxenes, zircon, and garnet were the most common minerals in the panned samples. Gold was found only in five samples (35 nuggets). The gold grain size varied from $150 \mu \mathrm{m}$ to $1 \mathrm{~mm}$. The morphology and composition of gold grains were investigated with a JMS-5510-JEOL scanning microscope (Department of Chemistry, Sofia University, Bulgaria). The chemical composition of gold was determined by $\mathrm{X}$-ray structural analysis with a TRACTOR NORTHERN TN-2000 microprobe and JEOL LMS $35 \mathrm{CF}$ electron microscope. Measurements were carried out based on the JEOL standards at a voltage of $25 \mathrm{kV}$ for samples $2 \times 10^{-9} \AA$ in size. Microprobe analyses were also carried out with a Philips SEM 505 electronic microscope (EDAX model 91000/60, voltage $20 \mathrm{kV}$ ) in the Central Laboratory of Photoprocesses, Bulgaria. Gold grains have elongate, isometric, and oval shapes (Fig. 3), suggesting their input from a primary bedrock source [5]. The gold grains display a zonal porous internal structure (Fig. 3 ).

Microprobe analyses of the chemical composition of gold (Table 2) revealed that they represent native gold with a high fineness (834-981).

Silver occurs as an admixture $(0.82-15.85 \mathrm{wt} \%)$. Some grains demonstrate internal zonality: the central part is depleted in Ag relative to the periphery. In general, gold aggregates have a homogeneous composition. However, grain BD-9 is characterized by a very high fineness (977-984) and low $\mathrm{Ag}$ content (0.821.09\%).

The Ag content varies from 7.62 to $48.91 \%$ in some samples. The gold also contains $\mathrm{Fe}(0.02-0.05 \%)$. The $\mathrm{Cu}$ admixture is relatively uniform $(0.4-0.6 \%)$. The average $\mathrm{Au}$ content in gold grains from the Borov Dol deposit varies from 88.44 to $98.15 \%$ (average $91.20 \%$ ). The average content of admixtures in gold is as follows (\%): $\mathrm{Ag} \mathrm{7.87,} \mathrm{Fe} 0.036$, and $\mathrm{Cu} 0.49$ (Fig. 4). The min-

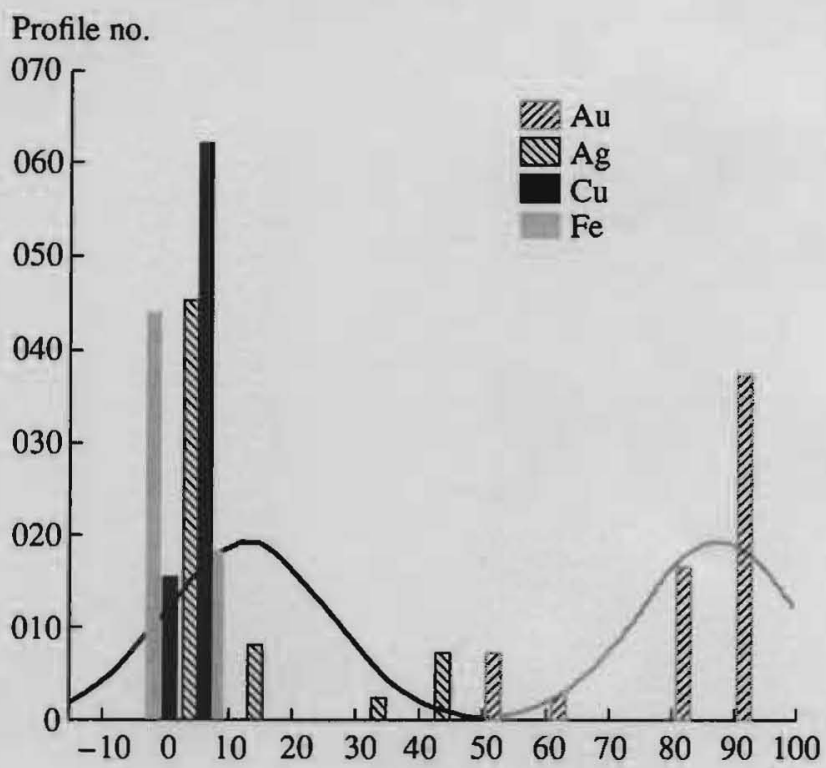

Fig. 4. Bar chart of the distribution of $\mathrm{Au}, \mathrm{Ag}, \mathrm{Cu}$, and $\mathrm{Fe}$ in the panned gold from the Borov Dol deposit.

eralogical-geochemical analyses revealed that gold from the porphyry copper deposits in the BučimDamian-Borov Dol ore region (Macedonia) are characterized by typomorphic features. The gold contains Fe and $\mathrm{Cu}$. Its chemical composition does not depend on the morphology of grains. Their morphology suggests the proximity to a bedrock source (Table 2 ).

Hence, the composition and morphology of grains serve as a prospecting guide for the porphyry copper mineralization. Panning and investigation of the typomorphism of gold can serve as an efficient tool in the prospecting for porphyry copper deposits.

\section{REFERENCES}

1. I. N. Tomson, T. Serafimovski, and N. T. Kochieva, Geol. Ore Deposits 40, 175 (1998) [Geol. Rudn. Mestorozhd. 40, 195 (1998)].

2. T. Serafimovski, Metallogeny of the Leche-Chalkidiki Zone (Rudar.-Geol. Fakultet, Shtip, 1990).

3. S. Karamata, R. Stojanov, T. Serafimovski, et al., Geol. Macedonica 6, 125 (1992).

4. N. Tudzarov and T. Serafimovski, Geol. Macedonica 9, 89 (1995).

5. N. V. Petrovskaya, Native Gold (Nedra, Moscow, 1973).

6. S. Jankovic, M. Petkovic, I. N. Tomson, and V. C. Kravcov, in European Copper Deposits, SGA Spec. Publ. No. I (UNESCO-IGSP-Projects No. 169, Belgrade, 1980), pp. 96-103. 